Огляди літератури, оригінальні дослідження, погляд на проблему, випадок з практики, короткі повідомлення УДК 616.127-06:615.217.24:(616.311.2+616.314.17)-002]-092.9-085.272

DOI 10.11603/1811-2471.2019.v0.i2.10375

\title{
ЗНАЧЕННЯ ПРОЦЕСІВ ЛІПОПЕРОКСИДАЦІї ТА АКТИВНОСТІ АНТИОКСИДАНТНОї СИСТЕМИ В МІОКАРДІ ЗА УМОВ РОЗВИТКУ АДРЕНАЛІНОВОГО ПОШКОДЖЕННЯ МІОКАРДА ПРИ ЕКСПЕРИМЕНТАЛЬНОМУ ПАРОДОНТИТІ ТА КОРЕКЦІЯ ЇХ ПОРУШЕНЬ КОРВІТИНОМ
}

\author{
Львівський національний медичний університет імені Данила Галицького
}

РЕЗЮмЕ. Значення процесів ліпопероксидації та активності антиоксидантної системи є факторами, які можуть впливати на розвиток та прогресування як адреналінового пошкодження міокарда (АПМ), так і пародонтиту. Однак у літературі ми не знайшли повідомлень про значення таких показників як дієнові кон'югати (ДК), малоновий діальдегід (МДА), супероксиддисмутаза (СОД), каталаза (КТ) та церулоплазмін (ЦП) при поєднанні АПМ та пародонтиту, а також про методи їх корекції корвітином.

Мета - оцінити значення показників ліпопероксидації та активності антиоксидантної системи в міокарді за умов розвитку адреналінового пошкодження міокарда при експериментальному пародонтиті до та після корекції корвітином.

Матеріал і методи. Досліди проведено на 54 білих щурах-самцях, яких поділили на шість груп (9 тварин у кожній). Перша-контрольна, друга, третя, четверта іп'ята-групитварин зАПМпідчасперебігуекспериментального пародонтиту (ЕП) відповідно на 1, 7, 10 і 17 доби експерименту без корекції корвітином, шоста група відповідно на 17 добу - тварини з АПМ під час перебігу ЕП з корекцією корвітином. Під час експерименту забирали тканину міокарда щурів та оцінювали вміст дієнових кон'югатів (ДК), малонового діальдегіду (МДА), супероксиддисмутази (СОД), каталази (КТ), церулоплазміну (ЦП).

Результати. У тварин з поєднаною патологією АПМ та пародонтитом без корекції корвітином результати показали підвищення показників дієнових кон'югатів і малонового діальдегіду та пригнічення показників супероксиддисмутази, каталази і церулоплазміну. А при цих поєднаних патологіях з їх корекцією корвітином встановлено зворотне - зниження показників дієнових кон'югатів і малонового діальдегіду та збільшення супероксиддисмутази, каталази і церулоплазміну.

Висновок. У піддослідних щурів з поєднаним перебігом АПМ та пародонтитом відбувається інтенсивніший розвиток оксидативного стресу, що може бути проявом посилення двох поєднаних патологій, особливо без корекції корвітином. А корекція препаратом з антиоксидантними властивостями показала зменшення розвитку оксидативного стресу, підвищення процесів антиоксидантного захисту та зниження нагромадження продуктів пероксидного окиснення ліпідів (ПОЛ).

КЛючОВІ СЛОВА: адреналінове пошкодження міокарда; пародонтит; корвітин; антиоксидантна система.

Вступ. На сьогодні серцево-судинна патологія, як одна з основних причин смертності та інвалідності людей працездатного віку, залишається актуальною проблемою. Згідно з даними ВООЗ, смертність від цієї патології у нашій країні становить понад 50 \%. Серед хворих переважають чоловіки, проте смертність є вищою у жіночій когорті, особливо серед осіб похилого віку [1]. Життя сучасної людини супроводжується величезною кількістю стресів, викликаних найрізноманітнішими причинами. У такому стані порушуються адаптаційні можливості організму, у ньому виникають функціональні, а далі й органічні зміни, наслідком яких є некротичне ушкодження міокарда [2]. Останніми десятиліттями особливу увагу приділяють одному з важливих молекулярних механізмів пошкодження клітин, що охоплює процеси пероксидного окиснення ліпідів (ПОЛ) і антиоксидантну систему (AOC) при АПМ.

Дистрофічно-запальні захворювання пародонта $є$ найпоширенішою патологією в стомато- логії. Генералізований пародонтит має не тільки різні клінічні прояви, а й різну динаміку патологічного процесу в пародонті у кожного хворого [3]. Розвиток генералізованого пародонтиту слід розглядати як результат взаємодії мікробного чинника й організму хворого. На сьогодні різнобічно вивчений вплив мікробного, травматичного, імунного, судинного та інших місцевих факторів у розвитку генералізованого пародонтиту. 3 однієї сторони, перебіг місцевої запальної реакції залежить від імунобіологічних властивостей організму пацієнта, з іншого - вогнище запалення в тканинах пародонта впливає на цілий організм. Виникає замкнуте коло, що погіршує репарацію пошкоджених тканин і відновлення гомеостазу [4]. Причинами відсутності стійкого ефекту після проведеної терапії з приводу пародонтиту можуть бути як дисбіотичні явища в порожнині рота із порушенням стабільності нормальної мікрофлори, так і зміни реактивності організму в цілому. Цьому сприяють ріст агресивності навколиш- 
Огляди літератури, оригінальні дослідження, погляд на проблему, випадок з практики, короткі повідомлення нього середовища, вплив стресорних факторів, збільшення серед населення осіб з різного роду імунодефіцитами, нераціональне застосування антибіотиків [5]. Не виключено, що й комплексна терапія генералізованого пародонтиту, яка включає використання антимікробних засобів із широким спектром дії, може сприяти тотальному пригніченню ендогенної мікрофлори порожнини рота й усіх ланок захисту [6].

Визнана необхідність розробки комплексного лікування захворювань пародонта і супутніх захворювань різних систем організму $[8,9]$. Це пов'язано з низкою медико-соціальних факторів i, зокрема, з високою частотою втрати зубів унаслідок генералізованого пародонтиту в молодих осі6 $[7,10]$ (35-44 роки) та старшого покоління. На сьогодні для корекції порушень, викликаних тривалим запальним процесом, у вигляді терапії супроводу часто використовують біофлавоноїди. Вони мають антиоксидантні, мембрано- та ангіопротекторні, протизапальні, імуномодулювальні властивості тощо [11], серед яких важливе значення має корвітин.

Мета - з'ясувати значення показників ліпопероксидації та активності антиоксидантної системи в міокарді за умов розвитку адреналінового пошкодження міокарда при експериментальному пародонтиті до та після корекції корвітином.

Матеріал і методи дослідження. Досліди проведено на 54 нелінійних білих щурах-самцях масою тіла 0,17-0,21 кг, яких поділили на шість груп (по 9 тварин у кожній). Перша - контрольна, друга, третя, четверта і п'ята - групи тварин 3 адреналіновим пошкодженням міокарда (АПМ) під час перебігу експериментального пародонтиту (ЕП) без корекції корвітином відповідно на 1, 7, 10 і 17 доби експерименту та шоста група - тварини з адреналіновим пошкодженням міокарда під час перебігу експериментального пародонтиту 3 корекцією корвітином, який вводили внутрішньоочеревинно у дозі 40 мг/кг маси тіла тварин з 10 по 17 добу експерименту. Гостре адреналінове ушкодження міокарда моделювали шляхом одноразового внутрішньоочеревинного введення 0,18 \% адреналіну гідротартрату ("Дарниця», Україна) $з$ розрахунку 1 мг/кг за методом О. О. Маркової [12]. Модель експериментального генералізованого парадонтиту відтворювали за методом О. І. Сукманського, О. А. Макаренка шляхом використання модифікованої дієти для щурів м'якої консистенції з високим вмістом вуглеводів [13]. Тварин виводили з експерименту на 1, 7, 10 i 17 доби відповідно до груп під налбуфіновим наркозом внутрішньоочеревинно дозою 182 мг/кг маси тіла щура [14] і забирали тканини міокарда для біохімічних досліджень. Експеримент був

проведений згідно з принципами біоетики відповідно до положень Європейської конвенції щодо захисту хребетних тварин, яких використовують в експериментальних та інших наукових цілях (Страсбург, 1986 р.), Директиви Ради Європи 2010/63/EU, Закону України № 3447-IV «Про захист тварин від жорстокого поводження», загальних етичних принципів експериментів на тваринах, ухвалених Першим національним конгресом України з біоетики Львівського національного медичного університету імені Данила Галицького (протокол № 4 від 18 січня 2017 р.). Вміст дієнових кон'югатів (ДК) визначали за методом В. Г. Гаврилова [15], малоновий діальдегід (МДА) - за методом Е. Н. Коробейнікової [16], супероксиддисмутази (СОД) - за методом R. Fried [17], каталази (KT) - за методом R. Holmes [18], церулоплазмін (ЦП) - за методом В. Г. Колб, В. С. Камишнікова [19]. Одержані цифрові результати були опрацьовані статистично методом Стьюдента.

Результати й обговорення. В результаті біохімічних досліджень встановили, що на 1, 7, 10 і 17 доби формування адреналінового пошкодження міокарда (АПМ) під час перебігу експериментального пародонтиту (ЕП) без корекції корвітином спостерігалось зростання вмісту в міокарді дієнових кон'югатів (ДК) відповідно на 54,2 \% $(p<0,05), 74,8 \%(p<0,05), 90,9 \%(p<0,05), 105,5 \%$ $(p<0,05)$ проти групи інтактних тварин (рис. 1). Визначення іншого показника ПОЛ - малонового діальдегіду (МДА) в міокарді показало аналогічний напрямок порушень. Цей показник підвищується на $83,3 \%(p<0,05), 65,0 \%(p<0,05), 71,0 \%(p<0,05)$, $84,7 \%$ ( $p<0,05)$ відповідно на 1, 7, 10 і 17 доби АПМ та ЕП без введення корвітину відносно контролю, що свідчило про активацію процесів вільнорадикального окиснення (ВРО) (див. рис. 1). Таким чином, дослідження маркерів ВРО в динаміці формування кардіоміопатії показало поступову стимуляцію процесів ліпопероксидації. Відомо, що надмірне утворення продуктів ПОЛ виснажує антиоксидантну систему. Разом із вивченням порушень прооксидантної системи досліджували особливості змін антиоксидантного захисту за показниками активності супероксиддисмутази (СОД), каталази (КТ), вміст церулоплазміну (ЦП) в міокарді у динаміці формування АПМ та ЕП без корекції. Встановлено, що на 1 добу активність СОД зростає на $56,96 \%(p<0,05)$, не зазнає змін на 7 добу, а далі - знижується на 10 і 17 доби відповідно на $65,98 \%(p<0,05)$ і $71,0 \%(p<0,05)$ проти першої групи тварин. Аналогічно змінювалася активність КТ, яка підвищувалася на 66,6 \% $(p<0,05)$ на 1 добу та не відрізнялася від показників контролю на 7 добу, а згодом, на 10 і 17 доби, при кардіоміопатії та пародонтиті відбувається ії̈ зниження відпо- 
Огляди літератури, оригінальні дослідження, погляд на проблему, випадок з практики, короткі повідомлення відно на $76,7 \%(p<0,05)$ і 80,8 \% $(p<0,05)$ відносно інтактної групи білих щурів-самців (див. рис. 1). Вміст ЦП зростає на 55,3\% $(p<0,05)$ на 1 добу, не зазнає змін на 7 добу, а далі знижується на $68,4 \%$ $(p<0,05)$ і 68,4 \% ( $p<0,05)$ відповідно до 10 та 17 діб порівняно з контролем (див. рис. 1). Також у результаті біохімічних досліджень на 17 добу формування адреналінового пошкодження міокарда (АПМ) під час перебігу експериментального пародонтиту (ЕП) з корекцією корвітином виявили спадання вмісту в міокарді дієнових кон'югатів (ДК) відповідно на $35,4 \%(p<0,05)$ проти групи тварин на 1 добу (рис. 2). Рівень малонового діальдегіду (МДА) в міокарді теж спадав на 27,6 \% $(p<0,05)$, відповідно на 17 добу АПМ та ЕП з введенням корвітину відносно інтактної групи тварин. Показники активності супероксиддисмутази (СОД), каталази (КТ), вміст церулоплазміну (ЦП) в міокарді у динаміці формування АПМ та ЕП з корекцією корвітином на 17 добу зростали на 130,1 \% (p<0,05), 88,4 \% $(p<0,05), 116,7 \%(p<0,05)$ відповідно, порівняно 3 контрольною групою тварин.

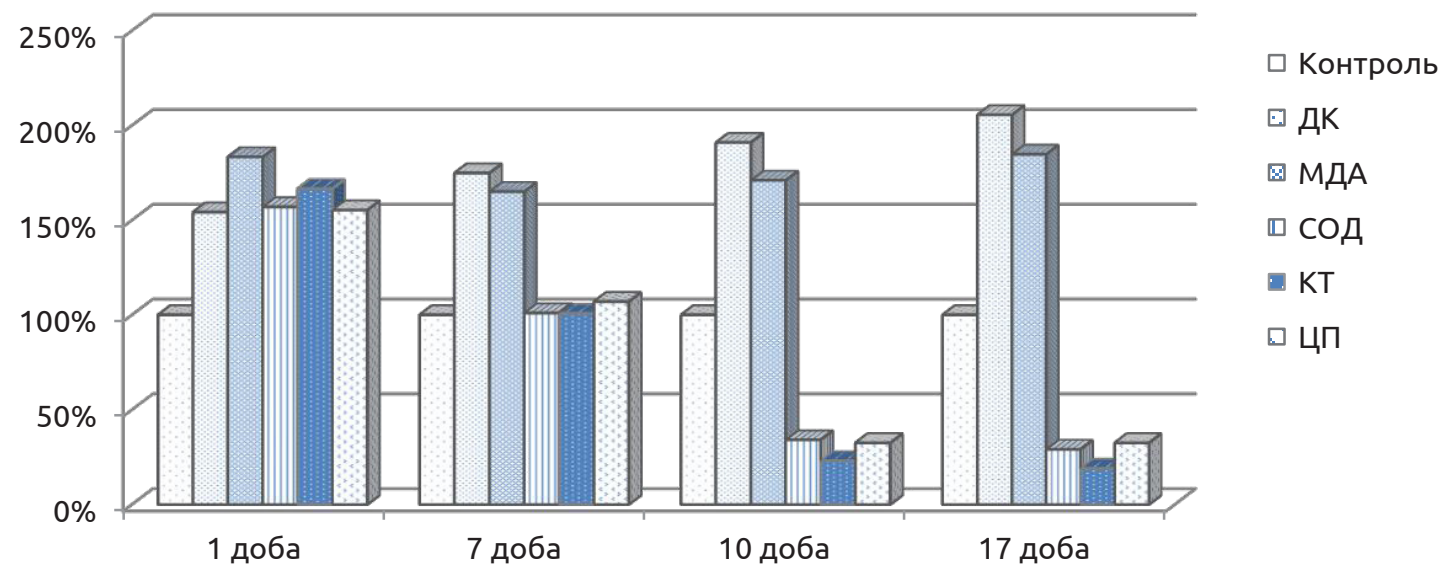

Рис. 1. Рівень продуктів ліпопероксидації та активності антиоксидантної системи в міокарді щурів за умов розвитку АПМ при ЕП без корекції корвітином (\% порівняно з контролем).

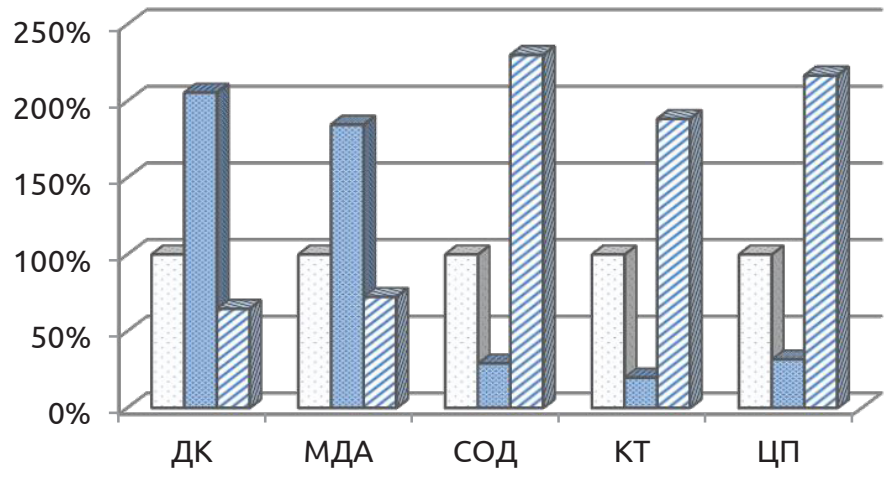

$\square$ Контроль

문 17-а доба АПМ і ЕП без корекції

๑ 17-а доба АПМ іЕП з корекцією

Рис. 2. Рівень продуктів ліпопероксидації та активності антиоксидантної системи в міокарді за умов розвитку АПМ при експериментальному пародонтиті без корекції корвітином (\% порівняно з контролем).

Висновки. При пародонтиті на тлі адреналінового пошкодження міокарда без корекції корвітином визначення маркерів ВРО (ДК і МДА) та АОС (СОД, КТ, ЦП) в міокарді показало поступову стимуляцію процесів ПОЛ та компенсаторне зростання активності досліджуваних ферментів з наступною депресією антиоксидантного захисту, особливо на 10 і 17 доби формування поєднаної патології, що вказує на розвиток оксидативного стресу. Разом з введенням корвітину під час поєднаної патології показники відрізняються, а саме - маркери ВРО (ДК і МДА) та АОС (СОД, КТ, цП) в міокарді показали кращі результати процесів ПОЛ, порівняно з експериментальними групами тварин з ЕП і АПМ на 17 доби дослідження, яким він не вводився, та спостерігається поступова стимуляція системи антиоксидантного захисту і зниження продуктів ПОЛ. Препарат Корвітин запобігає подальшому розвитку дисбалансу антиоксидантної системи, обмежуючи запальні реакції. Цей ефект може бути викликаний антиоксидантними властивостями вказаного препарату. 
Огляди літератури, оригінальні дослідження, погляд на проблему, випадок з практики, короткі повідомлення ЛІТЕРАТУРА

1. Ратманова А. Сердечно-сосудистая заболеваемость и смертность - статистика по европейским странам / А. Ратманова // Medicine Review. - 2009. - № 1. C. 6-12.

2. Коваленко В. М. Міокардит: сучасні аспекти патогенезу та діагностики / В. М. Коваленко // Український ревматологічний журнал. - 2001. - № 1. - С. 18-22.

3. Данилевський Н. Ф. Заболевания пародонта / Н. Ф. Данилевський, А. В. Борисенко. - К. : Здоров'я, 2000. -461 с.

4. Иммунокоррекция при воспалительных заболеваниях пародонта / А. И. Рыбаков, В. Н. Исаев, Т. П. Иванюшко [и др.] // Імунологія. - 1996. - № 6. - С. 57-59.

5. Левицький А. П. Лизоцим вместо антибиотиков / А. П. Левицький. - Одеса, 2005. - 74 с.

6. Грудянов А. И. Применение таблетированых форм пробиотиков бифидумбактерина и ацелакта в комплексном лечении воспалительных заболеваний пародонта / А. И. Грудянов, Н. А. Дмитриєва, Е. В. Фоменко // Стоматология. - 2002. - № 1. - С. 39-43.

7. Антоненко М. Ю. Сучасні технології оптимізації комплексної профілактики захворювань пародонта / М. Ю. Антоненко, Л. Ф. Сідельнікова // Науковий вісник Національного медичного університету імені О. О. Богомольця. - 2010. - № 1. - С. 84-89.

8. Борисенко А. В. Состояние стоматологического статуса у лиц молодого возраста в зависимости от наличия заболеваний пародонта / А. В. Борисенко, И. А. Воловик // Современная стоматология. - 2016. № 1. - С. 28-34.

9. Борисенко А. В. Структурні зміни кровоносних судин ясен у молодих щурів зі спонтанною артеріальною гіпертензією за умов ії̈ корекції біпрололом, тіотриазоліном та кверцетином / А. В. Борисенко, О.В.Черкасова // Новини стоматології. - 2011. - № 1. - С. 60-63.

\section{REFERENCES}

1. Ratmanova, A. (2009). Serdechno-sosudistaya zabolevaemost i smertnost - statistika po yevropeiskim stranam [Cardiovascular morbidity and mortality - statistics on European countries]. Medicine Review, 1, 06-12 [in Russian].

2. Kovalenko, V.M. (2001). Viokardit: suchasni aspekty patohenezu i diahnostyky [Myocarditis: Modern aspects of pathogenesis and diagnosis]. Ukrainskyi revmatolohichnyi zhurnal - Ukrainian Rheumatological Journal, 1, 18-22 [in Ukrainian].

3. Danilevskiy, N.F., \& Borisenko, A.V. (2000). Zabolevaniya paradontita [Periodontal diseases]. Kyiv: Zdorovia [in Ukrainian].

4. Rybakov, A.I., Isaev, V.N,, \& Ivanushko, T.P. (1996). Imunokorektsiya privospalitelnykh zabolevaniyakh parodonta [Immunocorrection in inflammatory diseases of periodontal disease]. Immunologiya - Immunology, 6, 5759 [in Russian].

5. Levytskyy, A.P. (2005). Lizotsim vmesto antibiotikov [Lysozyme instead of antibiotics]. Odesa [in Russian].
10. Host response mechanisms in periodontal / N. Silva, L. Abusleme, D. Bravo [et al.] // J. Appl. Oral Sci. [online]. - 2015. - Vol. 23, No. 3. - P. 329-355. Access mode : http://dx.doi.org/10.1590/ 1678-775720140259.

11. Chen K. T cell-mediated host immune defenses in the lung / K. Chen, K. Kolls // Annu. Rev. Immunol. - 2013. Vol. 31. - P. 605-633.

12. Маркова О. О. Міокардіодистрофія і реактивність організму / О. О. Маркова - Тернопіль : Укрмедкнига, 1998. - 152 с.

13 Сукманський О. І. Експериментальна модель генералізованого пародонтиту / О. І. Сукманський, О. А. Макаренко // Вісник стоматології. - 2006 - № 2. C. 2-3.

14. Errick J. Nalbuphine / J. Errick, R. Heel // Drugs. 1983. - Vol. 26 (3). - P. 191-211.

15. Гаврилов В. Б. Спектрофотометрическое определение содержания гидроперекисей липидов в плазме крови / В. Б. Гаврилов, М.И. Мишкорудная // Лабораторная диагностика ишемической болезни сердца. К. : Здоров'я, 1989. - С. 170-171.

16. Коробейникова $€$. Н. Модификация определения продуктов ПОЛ в реакции с тиобарбитуровой кислотой / Є. Н. Коробейникова // Лаб. дело. - 1989. № 7. - C. 8-10.

17. Fried R. Enzymatik and non-enzymatic assay of superoxideifilii / R. Fried // Biochemie. - 1975. - Vol. 57, No. 5. - P. 657-660.

18. Holmes R. Epigenetic interconversions of the multiple forms of mouse liver catalase / R. Holmes, C. Masters // FEBS Lett. - 1970. - Vol. 11, No. 11. - P. 45-48.

19. Колб В. Г. Определение активности церулоплазмина в крови: справочник по клинической химии / Колб В. Г., Камишніков В. С. - Минск : Беларусь - 1982. С. 290-291.

6. Grudyanov, A.I., Dmitrieva, N.A., \& Fomenko, E.V. (2002). Primeneniya tabletovanykh form probiotikov bifidymbakterina i azelakta v kompleksnom lechenii vospalitelnykh zabolevaniy parodonta [Application of tablet forms of probiotics of bifidumbacterin and acetalct in the complex treatment of inflammatory periodontal diseases]. Stomatologiya -Dentistry, 1, 39-43 [in Russian].

7. Antonenko, M.Yu., Sidelnikova, L.F. (2010). Suchasni tekhnolohii optymizatsii kompleksnoi profilaktyky zakhvoruvan parodonta [Modern technologies of optimization of complex prophylaxis of periodontal diseases]. Naukovyi visnyk Natsionalnoho medychnoho universytetu im. O. Bohomoltsia - Scientific Bulletin of O. Bohomolets National Medical University, 1, 84-89 [in Ukrainian].

8. Borisenko, A.V., \& Volovik, I.A. (2016). Sostoyanie stomatologicheskogo statusa i lits molodogo vozrasta $v$ zavisimosti ot nalichiya zabolivaniy parodonta [Condition of dental status in young people depending on the presence of periodontal diseases]. Sovremennaya stomatologiya Modern Dentistry, 1, 28-34 [in Russian]. 
Огляди літератури, оригінальні дослідження, погляд на проблему, випадок з практики, короткі повідомлення

9. Borisenko, A.V., \& Cherkasova, O.V. (2011). Strukturni zminy krovonosnykh sudyn iasen u molodykh shchuriv zi spontannoiu arterialnoiy hipertenziieiu za umov ii korektsii biprololom, tiotryazolinom ta kvertsetynom [Structural changes in the blood vessels of the gums in young rats with spontaneous arterial hypertension under conditions of its correction with biprolol, thiotriazoline and quercetin]. Novyny stomatolohii - News of Dentistry, 1, 60-63 [in Ukrainian].

10. Silva, N., Abusleme, L., \& Bravo, D. (2015). Host response mechanisms in periodontal diseases. J. Appl. Oral Sci., 23 (3), 329-355. Retrieved from: http://dx.doi. org/10.1590/ 1678-775720140259.

11. Chen, K. \& Kolls, K. (2013). T cell-mediated host immune defenses in the lung. Anna Rev. Immunol., 31, 605633.

12. Markova, O.O. (1998). Miokardiodystrofiia i reaktyvnist orhanizmu [Myocardial dystrophy and reactivity of the organism]. Ternopil: Ukrmedknyha [in Ukrainian].

13. Sukmanskyi, O.I., \& Makarenko, O.A. (2006). Eksperymentalna model heneralizovanoho parodontytu [Experimental model of generalized periodontitis]. Visnyk stomatolohii - Bulletin of Dentistry, 2, 2-3 [in Ukrainian].
14. Errick, J., \& Heel, R. (1983). Nalbuphine. Drugs, 26 (3), 191-211.

15. Gavrilov, V.B., \& Mishkoroudnaya, M.I. Spektrofotometricheskoye opredelenie soderzhanie gidroperikesey lipidov v plazme krovi [Spectrophotometric determination of the content of lipids hydroperoxides in blood plasma]. Laboratory diagnostics of ischemic heart disease]. Kyiv: Zdorovia [in Russian].

16. Korobeynikova, Ye.N. (1989). Modifikatsiya opredeleniya produktov POL v reaktsii s tiobarbiturovoy kislotoy [Modification of the definition of the products of the LPO in reaction with thiobarbituric acid]. Laboratornoye delo-Laboratory Case, 7, 8-10 [in Russian].

17. Fried, R. (1975). Enzymatik and non-enzymatic assay of superoxideifilii. Biochemie, 57 (5), 657-660.

18. Holmes, R., \& Masters, C. (1970). Epigenetic interconversions of the multiple forms of mouse liver catalase. FEBS Lett, 11 (11), 45-48.

19. Kolb, V.G., \& Kamishnikov, V.S. (1982). Opredeleniye aktivnosti tsereloplazmina v krovi; Spravochnik po klinicheskoy khimii [Determination of the activity of ceruloplasmin in the blood; Directory of Clinical Chemistry]. Minsk: Belarus [in Russian].

\title{
ЗНАЧЕНИЕ ПРОЦЕССОВ ЛИПОПЕРОКСИДАЦИИ И АКТИВНОСТИ АНТИОКСИДАНТНОЙ СИСТЕМЫ В МИОКАРДЕ В УСЛОВИЯХ РАЗВИТИЯ АДРЕНАЛИНОВОГО ПОВРЕЖДЕНИЯ МИОКАРДА ПРИ ЭКСПЕРИМЕНТАЛЬНОМ ПАРОДОНТИТЕ И КОРРЕКЦИЯ ИХ НАРУШЕНИЙ КОРВИТИНОМ
}

\author{
Львовский национальный медицинский университет имени Данила Галицкого
}

РЕЗЮМЕ. Значение процессов липопероксидации и активности антиоксидантной системы являются факторами, которые могут влиять на развитие и прогрессирование как адреналинового повреждения миокарда (АПМ), так и пародонтита. Однако в литературе мы не нашли сообщений о значении таких показателей как диеновые конъюгаты (ДК), малоновый диальдегид (МДА), супероксиддисмутаза (СОД), каталаза (КТ) и церулоплазмин (ЦП) при сочетании АПМ и пародонтита, а также о методах их коррекции корвитином.

Цель - оценить значение показателей липопероксидации и активности антиоксидантной системы в миокарде в условиях развития адреналинового повреждения миокарда при экспериментальном пародонтите до и после коррекции корвитином.

Материал и методы. Опыты проведены на 54 белых крысах-самцах, которых поделили на шесть групп (по 9 животных в каждой). Первая - контрольная, вторая, третья, четвертая и пятая - группы животных с АПМ во время течения экспериментального пародонтита (ЭП) соответственно на 1, 7, 10 и 17 сутки эксперимента без коррекции корвитином, шестая группа соответственно на 17 сутки - животные с АПМ во время течения ЭП с коррекцией корвитином. Во время эксперимента забирали ткань миокарда крыс и оценивали содержание диеновых конъюгатов (ДК), малонового диальдегида (МДА), супероксиддисмутазы (СОД), каталазы (КТ), церулоплазмина (ЦП).

Результаты. У животных с сочетанной патологией АПМ и пародонтитом без коррекции корвитином результаты показали повышение показателей диеновых конъюгатов и малонового диальдегида и угнетение показателей супероксиддисмутазы, каталазы и церулоплазмина. А при этих объединенных патологиях с их коррекцией корвитином установлено обратное - снижение показателей диеновых конъюгатов и малонового диальдегида и увеличение супероксиддисмутазы, каталазы и церулоплазмина.

Вывод. У подопытных крыс с совмещенным ходом АПМ и пародонтитом происходит интенсивное развитие оксидативного стресса, который может быть проявлением усиления двух соединенных патологий, особенно без коррекции корвитином. А коррекция препаратом с антиоксидантными свойствами показала уменьшение развития оксидативного стресса, повышение процессов антиоксидантной защиты и снижение накопления продуктов перекисного окисления липидов (ПОЛ).

КЛЮчЕВЫЕ СЛОВА: адреналиновое повреждение миокарда; пародонтит; корвитин; антиоксидантная система. 
Огляди літератури, оригінальні дослідження, погляд на проблему, випадок з практики, короткі повідомлення

\section{SIGNIFICANCE OF LIPOPEROXIDATION PROCESSES AND ACTIVITY OF ANTIOXIDANT SYSTEM IN THE MYOCARDIUM UNDER THE CONDITIONS OF DEVELOPMENT OF ADRENALINE MYOCARDIAL DAMAGE DURING EXPERIMENTAL PERIODONTITIS AND CORRECTION OF THEIR DISORDERS WITH COVARIATE}

○O. T. Horodetskyy, M. S. Regeda

\section{Danylo Halytskyi Lviv National Medical University}

SUMMARY. The significance of lipid peroxidation and antioxidant activity are some of the factors that can affect the development and progression of both adrenaline injury of myocarditis (AIM) and periodontitis. However, in the literature, we found no reports of value indicators such as diene conjugates (DC), malondialdehyde (MDA), superoxide dismutase (SOD), catalase (CT) and ceruloplasmin (CP) under AIM comorbidity and periodontitis, and methods of correction of corvitin.

The aim of the study - to evaluate the values of lipid peroxidation and antioxidant system activity in the myocardium under the conditions of epinephrine myocardial damage during experimental periodontitis before and after corvitin correction.

Materials and Methods. Experiments were conducted on 54 white male rats, which were divided into six groups (9 animals in each). Group 1 - the control, groups 2, 3, 4 and 5 - the group of animals with AIM during the course of experimental periodontitis (EP), accordingly, in the 1-st, 7-th, 10-th and 17-th days of the experiment without correction of corvitin and group 6, accordingly, on the 17-th day - animals with AIM and during EP with the course of correction of corvitin. During the experiment, the tissue of the myocardium of rats was collected and evaluated the content of diene conjugates (DC), malonic dialdehyde (MDA), superoxide dismutase (SOD), catalase (CT), ceruloplasmin (CP) was measured.

Results. In animals with a combined pathology of AIM and periodontitis without correction of corvitin, the results showed an increase in the indications of diene conjugates and malonic dialdehyde and decrease of superoxide dismutase, catalase and ceruloplasmin. And with these combined pathologies with their corvitin correction established the opposite - a decrease in the indices of diene conjugates and malonic dialdehyde and the growth of superoxide dismutase, catalase and ceruloplasmin.

Conclusion. In experimental rats with a combined course of AIM and periodontitis there is a more intensive development of oxidative stress, which may be a manifestation of the strengthening of two combined pathologies, especially without correction of corvitin. However, the correction with a drug with antioxidant properties showed a decrease in the development of oxidative stress, an increase in the antioxidant protection and a decrease in the accumulation of products of peroxide lipid oxidation (PLO).

KEY WORDS: adrenaline injury of myocarditis; periodontitis; corvitin; antioxidant system. 